\title{
THE SOCIAL, PERSONAL, AND SPIRITUAL DYNAMICS OF GHOST STORIES IN EARLY MODERN ENGLAND*
}

\author{
LAURA SANGHA \\ University of Exeter
}

\begin{abstract}
A B STRACT. In early modern England, spectral figures were regular visitors to the world of the living and a vibrant variety of beliefs and expectations clustered around these questionable shapes. Yet whilst historians have established the importance of ghosts as cultural resources that were used to articulate a range of contemporary concerns about worldly life, we know less about the social and personal dynamics that underpinned the telling, recording, and circulation of ghost stories at the time. This article therefore focuses on a unique set of manuscript sources relating to apparitions in late seventeenth- and early eighteenth-century England to uncover a different vantage point. Drawing on the life-writing and correspondence of the antiquarian who collected the narratives, it lays bare concerns about familial relations and gender that ghost stories were bound up with. Tracing the way that belief in ghosts functioned at an individual level also allows the recovery of the personal religious sensibilities and spiritual imperatives that sustained and nourished continuing belief in ghosts. This subjective angle demonstrates that ghost stories were closely intertwined with processes of grieving and remembering the dead, and they continued to be associated with theological understandings of the afterlife and the fate of the soul.
\end{abstract}

In the parish of Hovingham, North Yorkshire, in March 1707, something was amiss. The household of John Fawcet was suffering a haunting that was causing a 'great disturbance' to the family, disrupting their sleep and upsetting the servants. Every night for three weeks a knocking sound had been heard echoing through the house. On some occasions the knocking was uncomfortably close to the hearers, sometimes at the head of a bed, sometimes at the feet, sometimes on a table, or emanating from the ceiling. The source of the noise could not be found, and there seemed to be no natural explanation.

Department of History, University of Exeter, Exeter, EX4 4RJ l.s.sangha@ex.ac.uk

* My thanks to participants of the 'Inner Lives' University of East Anglia workshop 2017, to seminar audiences in Bristol and Manchester, and to the anonymous reviewers for their incisive comments and questions on earlier versions of this article. I am also particularly grateful to Sasha Handley for her generous engagement with an early draft, and to Mark Hailwood for his assistance in shaping the research for publication. 
Unsure what to do, the family sensibly sought out the advice of the minister of their church, Reverend William Wood. Wood advised that the Fawcets should attempt to communicate with the knocker. The family did as Wood suggested, telling the knocker to respond by knocking if the answer to a question was yes, and to refrain from knocking if the answer to a question was no. This tactic was successful, and by these means the knocker affirmed that it was the ghost of John Fawcet's grandmother-in-law, one Madam Savage.

The spirit appeared to be relatively benign, but it came with a purpose. Further questioning revealed that Savage had left certain things to her grandchildren in her will, but that after her death these had not been passed on to them as she had requested. The ghost indicated that it would only stop disturbing the family once these bequests had been fulfilled. John Fawcet therefore set off for Leeds, where his father-in-law Mr Johnson resided, to retrieve the properties and to hand them over to Savage's grandchildren. Some gold rings, linen, a gold watch, and several silver drinking vessels were duly located and passed on. However, though the household had been quiet whilst Fawcet was on his mission, on returning to Hovingham the disturbances began again and further questioning of the ghost revealed that this time $\mathrm{Mr}$ Johnson was to blame. The ghost then made its first, and apparently only, visual appearance. It manifested before a maidservant, taking the shape of 'an ancient Gentlewoman grey-headed'. The spirit spoke to the servant, saying that her name was Savage, that Johnson had 'unworthily defrauded her Grandchildren', and mentioning further properties that had been withheld from the orphans by Johnson. Despite these clear instructions on how to rid the household of the ghost, Johnson proved obdurate, and the spirit became more troublesome, 'taking the bed staves and throwing them about' and 'putting off the bedclothes' of the family. News of the ghost spread throughout the Fawcet's hometown of Scackleton and beyond, and many witnesses outside of the family were ready to testify to the authenticity of the haunting. Eventually, the spirit proved so bothersome that an observer noted the family themselves began to resemble the ghost that troubled them so.

In early modern England, ghosts, revenants and spectral figures were regular visitors to the world of the living and a vibrant variety of beliefs and expectations clustered about these questionable shapes. In his classic survey of contemporary popular belief in 1971, Keith Thomas sketched out the evolution of ghost beliefs and applied the interpretative techniques of social anthropology to argue that supernatural beliefs sprang from 'a preoccupation with the explanation and relief of human misfortune'. ${ }^{1}$ Thomas demonstrated that ghost beliefs personified women's and men's hopes and fears and provided a useful sanction for social norms. ${ }^{2}$ More recently, historians have built on this

${ }^{1}$ Keith Thomas, Religion and the decline of magic: studies in popular beliefs in sixteenth- and seventeenth-century England (London, 1971), p. 5 .

${ }^{2}$ Ibid., ch. 19. 
functional explanation, recovering further meanings and in many cases attributing ghost beliefs with a cultural autonomy and causal power. Ghost beliefs have proved significant for understanding the process of the Protestant Reformation and for exploring social expectations surrounding death. ${ }^{3}$ Historians have also established the importance of ghosts as cultural resources that were used to articulate a range of contemporary concerns about daily life, or new fictional spaces where memory, identity, and landscape could be explored. 4

This scholarship perhaps obscures the methodological difficulties facing the historian of ghost beliefs, particularly for one interested in non-elite or nonlearned believers. Simply claiming that you had seen a ghost was not enough to bring you to the attention of the early modern authorities, so unlike with witches, the records of the secular or ecclesiastical courts contain very little evidence relating to apparitions. Although ghosts feature in a number of publications about the supernatural more broadly, there was no native English treatise on them before the Civil Wars, so scholars have generally been forced to sift painstakingly though works of theology, literary sources, and cheap print in order to recover public and private perceptions surrounding them. However, this story of the ghost of Madam Savage has been reconstructed from two accounts of the haunting that survive in the papers of the Leeds antiquarian and pious diarist Ralph Thoresby $\left(165^{8-1725}\right)$. It is part of a distinctive set of manuscript sources relating to the appearances of apparitions in late seventeenth- and early eighteenth-century England.5 The collection was gathered together by Thoresby, and includes letters, written accounts, and brief notes on a range of different supernatural encounters, many of which took place in and around Yorkshire, Thoresby's home county. The rare survival of the Thoresby narratives means that they offer a unique opportunity to examine the emotional and spiritual dynamics of ghost beliefs, particularly at a social and personal level. Not only are Thoresby's narratives richly detailed, his private papers also include a diary and extensive correspondence that allow a

3 Thomas argued that belief about ghosts was a 'shibboleth' which distinguished Protestant from Catholic, but Peter Marshall has shown that the writings of reformers were structured by both theological debate as well as traditional or 'popular' expectations about ghosts. Thomas, Religion and the decline, ch. 19; Peter Marshall, 'Deceptive appearances: ghosts and reformers in Elizabethan England', in Helen Parish and Bill Naphy, eds., Religion and superstition in Reformation Europe (Manchester, 2003); Peter Marshall, Beliefs and the dead in Reformation England (Oxford, 2004), ch. 6.

4 Natalie Zemon Davis, 'Ghosts, kin, and progeny: some features of family life in early modern France', Daedalus, 106 (1977), pp. 87-114; Laura Gowing, 'The haunting of Susan Lay: servants and mistresses in seventeenth-century England', Gender and History, 41 (2002), pp. 183-201; Malcolm Gaskill, Crime and mentalities in early modern England (Cambridge, 2012 ), at pp. $217-19$.

5 All subsequent references to the Thoresby ghost narratives refer to the Thoresby Society Archive, the Leeds Library, SD 9 . 
deeper contextualization for the accounts, a prospect that printed sources have only rarely afforded.

Work on such printed materials has led to a firm consensus among scholars that there was a circularity of influences between ghost stories in oral and literature cultures and a strong interdependence between manuscript and print spheres, and close attention to the production, circulation, and consumption of ghost stories has demonstrated the ways in which they were adapted according to contemporary trends in intellectual and religious cultures. The scholarship demonstrates the social significance and diffusion of ghost beliefs, and establishes the ghost's credentials as a 'flexible imaginative resource' that was drawn on by a variety of people throughout the early modern period and beyond. ${ }^{6}$ The Thoresby narratives deepen our appreciation of the significance of this imaginative resource. The rich detail they contain can be compared with evidence in Thoresby's life-writing and correspondence in order to reconnect the stories with the social context from which they emerged. Most uniquely, they also offer a rare opportunity to examine the way that belief functioned on an individual level, and to reconstruct personal responses to ghost narratives. This article therefore uses the distinct qualities of the Thoresby collection to build a more intricate picture of the religious, social, personal and emotional dynamics that characterized early modern ghost narratives. By locating the ghost stories in the hands of a specific individual, it uncovers not only the way that apparitions were shaped into strategies for a variety of social and intellectual purposes, but also the personal religious sensibilities and spiritual imperatives that nourished and sustained an interest in apparitions. The Thoresby manuscript narratives reinforce our understanding of early modern belief about the nature and behaviour of ghosts, but the accounts also provide a new perspective on personal responses to ghost stories, and especially the emotional and religious resonances they carried and created.

The article begins by explaining the origins of the Thoresby narratives, before moving on to explore the familial and gendered dynamics behind the ghost of Madam Savage, the longest and most complete of the Thoresby accounts. It then considers one of the most striking features of the antiquarian's collection, the strong similarity in the types of supernatural activity that they recorded. Evidence from Thoresby's diary and correspondence is used to explicate this focus, and to indicate its probable origins in the antiquarian's personal experiences. I connect Thoresby's ghost stories to his own beliefs about the supernatural, dying, and the afterlife, and argue that his interest in ghost narratives was closely intertwined with processes of grieving and remembering the dead.

${ }^{6}$ Marshall, Beliefs and the dead; Peter Marshall, Mother Leakey and the bishop: a ghost story (Oxford, 2007); Sasha Handley, Visions of an unseen world: ghost beliefs and ghost stories in eighteenth-century England (London, 2007); Owen Davies, The haunted: a social history of ghosts (Basingstoke, 2007); Michael Hunter, "New light on the "drummer of Tedworth": conflicting narratives of witchcraft in Restoration England', Historical Research, 78 (2005), pp. 312-53. The phrase is Handley's in Visions of an unseen world, p. 21. 
Ultimately, I show that in alliance with his other personal papers, the Thoresby manuscripts reveal the personal and emotional dynamics of early modern ghosts - insights that are often effaced in printed narratives.

Ralph Thoresby was a middling sort from a family of moderate Presbyterian merchants, yet despite this nonconformist background he was to conform fully to the Church of England from 1697 onwards. He took over his family's business concerns when he was twenty-one in 1679 , but he was able to retire in his forties, around 1704 , to dedicate his time entirely to his long-standing topographical and antiquarian pursuits. Thoresby published two histories of Leeds and his intellectual pursuits brought him into contact with numerous correspondents, including many of the great and the good in Restoration ecclesiastical and intellectual circles. His deep piety sustained a forty-eight-year lifewriting habit, and many of the volumes of his diary have survived covering

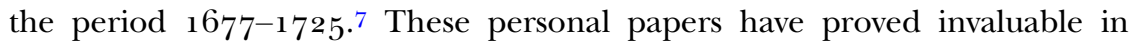
exploring and contextualizing the surviving supernatural accounts.

Thoresby's interest in supernatural narratives was informed by contemporary trends in intellectual and religious cultures. The latter half of the seventeenth century saw the rehabilitation of ghost stories as they lost their explicitly confessional overtones and were adopted by a range of churchmen for a variety of pastoral and polemical purposes. Deployed to reaffirm clerical supervision, theological moderation, and conformity, and recruited into campaigns to restore confessional harmony, seeing ghosts had never been more respectable in post-Reformation England. ${ }^{8}$ An important context for these shifts was the perceived rise of 'irreligion' and 'atheism' which supposedly thrived at court and in coffee houses. At the same time, natural and mechanical philosophy seemed to represent a new threat to belief in the supernatural, subjecting belief in the invisible world to a newly intense scrutiny. In response to these pressures, refutations of materialism quickly appeared in print, and polemicists adopted experimental methods to prove the existence of spirits and thus turn the weapons of mechanical philosophy against their advocates. A number of clergymen collected information and examples - proofs - of spiritual phenomena and published them in works that were explicitly intended to counter the

7 For more on Thoresby's background, see my forthcoming article 'Ralph Thoresby and individual devotion in late seventeenth- and early eighteenth-century England', Historical Research (in press). Five volumes of Thoresby's life-writing are in the University of Leeds Brotherton Library Special Collections, Yorkshire Archaeological Society (hereafter YAS) $\left(\right.$ MS $\left._{1-5}\right)$. Other volumes are held at York Minster Library and the Royal Library, Copenhagen.

${ }^{8}$ The shift in the status of ghost beliefs is noted by R. C. Finucane in Ghosts: appearances of the dead and cultural transformation (New York, NY, 1984), ch. 5 ; Handley, Visions of an unseen world, esp. ch. 1; Jo Bath and John Newton, "Sensible proof of spirits": ghost belief during the later seventeenth-century', Folklore, 117 (2006), pp. 1-14. 
perceived tide of scepticism. 9 All these collections included encounters with a colourful assortment of ghosts. The supernatural examples they included were drawn from classical texts and scripture, but they also contained contemporary narratives sent to the authors by correspondents. The authors were often known to each other, and they exchanged and recycled narratives of supernatural narratives freely, encouraging each other in the work.

The life-writing of the Leeds antiquarian Ralph Thoresby indicates that he had read many of these collections, and he mentioned by name those by Henry More, Joseph Glanvill, George Sinclair, Richard Baxter, Cotton Mather, and William Turner. ${ }^{10}$ Aside from More, the authors of these texts were clergymen, and the prefaces and content of the works indicate that they were all part of the counterattack provoked by the perceived threat of atheism. Thoresby's diary and surviving correspondence also reveals that he was himself an avid collector and disseminator of his own empirical proofs of the supernatural world, and he was gathering materials in anticipation of his own published collection. Although Thoresby died before his own work was completed and most of the material he gathered does not seem to have survived, a small collection of ghost narratives is preserved in the Thoresby Society archive, and it is this material that is the focus of this article.

What would Thoresby's printed collection have been like, had he completed it? It can be viewed in light of the printed collections that he was familiar with. Like Glanvill, Baxter, Turner, and the other clergymen authors, Thoresby also expressed concerns about the growth of unorthodox beliefs and scoffing wits, and he was well versed in the intellectual controversies of the day which he followed in print. For instance, on an evening in May 1722, Thoresby noted in his diary that he 'finished the perusal of the contents and index of Mr. Locke's Essay concerning Human Understanding', which he described as 'learned and curious, as the author, with whom I dined at the Earl of Pembroke's'. ${ }^{11}$ Thoresby was not only well read, he was also a part of a group of clergymen, natural philosophers, and scholars deeply committed to an anti-atheist agenda. The cornerstones of this group were the Cambridge Platonist Henry More, and Edward Fowler, the bishop of Gloucester, whilst Robert Boyle was

9 For more on these collections, see Michael Hunter, 'The decline of magic: challenge and response in early Enlightenment England', Historical Journal, 55 (2012), pp. 399-425, at pp. 405-9; Bath and Newton, "Sensible proof of spirits"; and Finucane, Ghosts, pp. 119-50.

${ }_{10}$ University of Leeds Brotherton Library Special Collections, YAS MS25, p. 29. All subsequent references to printed sources were consulted at the Early English Books Online Text Creation Partnership. Henry More, An antidote against atheisme (London, 1652); Joseph Glanvill, Saducismus triumphatus, or Full and plain evidence concerning witches and apparitions (London, 1681); George Sinclair, Satan's invisible world discovered (Edinburgh, 1685); Richard Baxter, The certainty of the world of spirits (London, 1691); Cotton Mather, The wonders of the invisible world (Boston, 1693); William Turner, A compleat history of the most remarkable providences (London, 1697).

11 University of Leeds Brotherton Library Special Collections, YAS MS25, p. 134. 
another interested party. ${ }^{12}$ In May 1712 , Thoresby met Fowler, who apparently urged Thoresby to publish his narratives of apparitions, since they 'might be of good use to convince the sceptical in an infidel age'. ${ }^{13}$

The extensive links between these men helps to explain the unity of purpose exhibited in their printed supernatural collections and it means that we can use these texts to get a sense of what Thoresby's finished work would have been like. The collections were all substantial, weighty tomes, which brought together various types of proof of the existence of the supernatural. Most were preceded by theological reflections on the natural world and the existence of God, with philosophical discussions of the nature of spirit, miraculous events, and the invisible world. All included examples of a wide range of supernatural phenomena, including prodigies, apparitions, premonitions, deliverances, visions, dreams, possession, and haunted houses. In many instances, the examples they contained had originally been conveyed to the authors in letters, sent by correspondents mainly in England but also from further afield. In the Glanvill and Turner collections, substantial evidence was also provided from the author's own experience. In most cases, the authors adhered to the standard of evidence that Simon Schaffer has shown was demanded by contemporary natural philosophers: the accounts were detailed, circumstantiated reports, validated by the author's probity and combined with autobiographical exactitude. ${ }^{14}$

Thoresby's life-writing affirms that his planned printed collection would also have been a mix of local, contemporary examples that he had himself uncovered, supplemented with reference to existing works and the manuscript collections of his associates. He transcribed examples of Turner's printed collection, and made extracts from the diary of Oliver Heywood and the daybook of the ejected minister Henry Sampson. This material included prodigious phenomena, apparitions, deliverances, visions, and cases of diabolical possession. ${ }^{15}$ However, it seems likely that the bulk of the collection would have been examples that were provided by Thoresby's personal acquaintance, giving his collection a distinctive character. There was a precedent for this in Richard Bovet's

${ }^{12}$ Glanvill corresponded with both Richard Baxter and Henry More and Glanvill's work was eventually posthumously edited by More. Fowler was another important supporter of Glanvill, and he contributed narratives to both his and John Beaumont's published complications. William Turner's work was the result of a collaboration with the editor of the Athenian Mercury, John Duntan, who in turn had connections with Fowler. Fowler encouraged Thoresby to collect material for publication when the two met in London in 1712.

13 University of Leeds Brotherton Library Special Collections, YAS MS26, p. 243.

14 S. Schaffer, 'Defoe's natural philosophy and the worlds of credit', in J. Christie and S. Shuttleworth, eds., Nature transfigured: science and literature, I7oo-I9oo (Manchester, 1989). See also Steven Shapin, A social history of truth: civility and science in seventeenth-century England (Chicago, IL, 1994); Peter Dear, Revolutionizing the sciences: European knowledge and its ambitions (Princeton, NJ, 2001).

15 See British Library Add. MS 446o, fos. 18v-24, 4ov-8o; University of Leeds Brotherton Library Special Collections, YAS MS1 7, pp. 41-2. 
Pandaemonium of 1684, which mainly related tales from Somerset and the West Country where the Bovet family had their home. Furthermore, in the last years of his life, Thoresby noted in his diary several occasions when he explicitly sought out narratives from people in Leeds. For instance, in 1722, a Mr Sagar told him an account of an apparition that he had seen, and in 1724, Thoresby described 'going abroad to get the relation of the apparition of Thomas Parkinson...from his nearest relations'. ${ }^{16}$

The small clutch of ghost narratives in Thoresby's personal papers also confirm the outline of Thoresby's methodology discussed above. Four of the eight accounts were narratives written by people other than Thoresby, but who were personally known to him. The folds in these four narratives strongly suggest that they had been circulated as enclosures in letters, which may have been how Thoresby received them - his surviving correspondence shows that the circulation of narratives as enclosures was a widespread practice in his circle. Two apparition accounts are included in letters: one was addressed to Reverend Benson, the lecturer in Leeds Old Church (St Peter's), the other addressed to Richard Baxter, which related four cases of apparitions that had appeared in Yorkshire some years before. There are also two briefer notes on a prophetic dream and two providential happenings in North Carolina. The former Thoresby had copied out of the daybook of an acquaintance and the latter related to a soldier who was born in a town nearby. This small sample of narratives in combination with Thoresby's other papers offers a rare opportunity to explore the social and personal resonances of the ghost stories. They not only represent an opportunity to consider the significance of apparition accounts in the context of the regional communities that produced them, but also provide scope for thinking about the subjective dimensions of these narratives, and the more personal motives that underpinned the telling, recording, and circulation of ghost stories at the time.

Although Thoresby did not write any of the supernatural accounts in his collection, he was connected with the haunting of the Fawcet household, the narrative that this article began with. The description of Madam Savage's ghost in the Thoresby papers demonstrates the social dynamics that underpinned contemporary ghost stories, illuminating their legitimate and effective status as narrative strategies. The Savage account reveals both how and why real life experiences of ghosts were translated from speech to manuscript communities as well as the ways that such narratives were bound up with class and gender. In addition, the story exposes the deep well of expectations about apparitions that

\footnotetext{
${ }^{16}$ Richard Bovet, Pandaemonium, or The devil's cloyster being a further blow to modern Sadduceism (London, 1684); University of Leeds Brotherton Library Special Collections, YAS MS25, pp. $152,220,193$.
} 
informed contemporary experience, the 'close layering' of Catholic and Protestant expectations, and the lack of consensus about what precisely to believe about ghosts in post-Reformation England. ${ }^{17}$

There were two accounts of Madam Savage's ghost, one provided by John Fawcet, the owner of the house that was haunted, and one provided by the Reverend William Wood, the rector of Dalby and an acquaintance of Fawcet. Characteristically, many of the correspondents and scribes in the Thoresby accounts were clergymen. In this case, Reverend Wood also played an active part in the development of the supernatural encounter, since he was consulted by John Fawcet about the best way to respond to the noisy disturbances, and he recommended asking the ghost a series of questions. When it transpired that the ghost wanted Fawcet to travel from York to Leeds to resolve an inheritance dispute, Wood seemingly accepted this explanation, accompanying Fawcet on his journey. The rector was later a witness to the knockings himself, and he was prepared to sign a testimony to that effect. In light of the dominant Protestant theological position about apparitions, Wood's reaction is rather surprising. According to contemporary theologians, the rector should have assumed that the spirit was a fraud, a delusion, or demonic in origin, since angels appeared only very rarely in the latter days, and purgatorial ghosts were no longer a possibility. In his treatise on ghosts that was translated into English in 1572 , the Zurich minister Ludwig Lavater offered Protestant theological advice on how to behave when confronted with a spirit. In direct contradiction of Wood's conduct, Lavater was particularly emphatic that no person should talk to a spirit or ask anything of them. ${ }^{18}$ Yet Wood's response is less surprising when considered alongside the supernatural collections discussed above, as these were authored by clergymen who were not timid about asserting their belief in apparitions. The stories relayed in cheap printed pamphlets also reinforce the impression that the reaction of clergymen to ghost stories was varied. ${ }^{19}$ The Savage case therefore further affirms the extent to which the orthodox notion of demonic apparitions was mitigated by traditional expectations as well as pastoral realities in Protestant religious cultures.

Many other characteristics of the Savage ghost also illustrate the themes of existing scholarship on early modern apparitions. Savage's ghost appeared as 'an ancient Gentlewoman grey-headed', and in the other Thoresby accounts, all except one of the spirits take the shape of a deceased person. The revenant

17 Marshall, Beliefs and the dead, p. 26o; idem, Mother Leakey and the bishop, ch. 2.

18 Lewes Lavater, Of ghosts and spirits walking by nyght (London, 1572), pp. 190-204. In another of the Thoresby accounts, Bishop Usher apparently accepted the existence of a spirit that was haunting Bridget Pointon.

19 Ministers are mentioned in Anon., Strange and true news from Long Alley in More-fields (London, 1661), p. 6; Anon., Strange and wonderful news from London-wall (London, 1674), p. 4; Anon., A true relation of the dreadful ghost appearing to one John Dyer (London, 1691), p. 3; Anon., The wonder of this age: or, God's miraculous revenge against murder (London, 1677), p. 3; Anon., The wonderful, strange, apparition and ghost of Edward Ashley (London, 1712 ), p. 5 . 
that haunted an Easington house took 'the likeness of a maid of the family', and Jane Piers was disturbed by the 'appearance' of her coachman. Like Savage's ghost, many of the spirits also manifested audibly too. A chaplain in the house of Esquire Overton in Easington heard such thumping and lumbering in the garret over his own that he feared the floor would come down on his head, and he testified that outside his door he heard a noise 'as if a woman descended, and her coats swept the stairs'. In the same house, a maidservant was 'extreamly affrighted' after hearing three 'hideous groanes' in the cellar, and in a rare Irish case, Bridget Pointon was disturbed by a ghost that called her name every night for three years, before it appeared to her as a milk white pigeon.

Typically, Savage's ghost was also a member of the family since 'Madam' Mary Savage had been married to Charles Savage, and John Fawcet had married Savage's granddaughter. Ralph Thoresby was involved in the case because his brother, Jeremy Thoresby, had married Madam Savage's daughter - another Mary. Both Madam Mary Savage and Mary Thoresby died in 1699, and Jeremy Thoresby passed away in 1702, leaving Ralph Thoresby as guardian of Jeremy and Mary's two orphaned children - yet another Mary, and Elizabeth. It was Thoresby's wards, Mary and Elizabeth, who were the two grandchildren that Grandmother Savage had left property to. In his diary, Thoresby mentioned taking in his orphaned nieces in 1702, as well as his transactions with John Fawcet and Fawcet's father-in-law, the obstinate Johnson. Thoresby tried hard to recover his wards' properties from both of these men and the property dispute was evidently long-standing when Thoresby travelled to York to investigate it after his brother's death in $1703 .{ }^{20}$ During the same journey, Thoresby also visited Johnson and his wife, finding their dealings with the orphans 'untoward' since the couple had removed the best linen, gold rings, and other property from various trunks in their possession. Indeed, Johnson's boxes were barely half full, with 'nothing but refuse left'. ${ }^{21}$

Thoresby does not make clear when Fawcet and Johnson opened these trunks and boxes, but that the dispute was not concluded satisfactorily is apparent from the appearance of the ghost four years later. The most plausible functional explanation for this ghost is therefore Fawcet's guilty conscience about his illgotten gains pricking him into making restitution. It is an explanation that fits closely with the way that contemporary ghost stories functioned as narrative strategies, for from the medieval era onwards the return of spirits to expose the location of concealed treasures, to repay forgotten debts, and to restore inheritance to the rightful heirs was a regular feature of these accounts. ${ }^{22}$ Concerns

\footnotetext{
${ }^{20}$ University of Leeds Brotherton Library Special Collections, YAS MS26, p. 168.

21 University of Leeds Brotherton Library Special Collections, YAS MS23, pp. $255,256$.

${ }^{22}$ Monk of Byland's ghost stories, trans. John Shinners from M. R. James 'Twelve medieval ghost stories', English Historical Review, 37 (1922), pp. 413-22, in John Shinners, ed., Medieval popular religion, IOoO-I 5oo: a reader (Peterborough, ON, 1997), pp. 229-37.
} 
over property also dominated later printed texts and were prominent in weightier treatises. Indeed, in the introduction to his text, Glanvill speculated that 'extraordinary detections of Murders, latent Treasures, falsified and unfulfill'd Bequests' were likely to be the 'courteous discoveries' of more benign apparitions. ${ }^{23}$

Yet reading between the lines, gender had an important role to play too, just as it did in many of the other accounts in Thoresby's collection where women were mentioned as witnesses. In the Fawcet case, not only did a female ghost return to redress a wrong committed against her two granddaughters, but other women were deeply implicated in the unfolding of the narrative at every stage. The maidservant provided the key evidence in the case, since she was the only person to see and speak directly to the ghost. Yet the maid's social status and gender meant that she was not necessarily a creditable witness, with the result that some 'scrupled' her testimony, and she was tested in order to rule out a possible fraud. In a note added to the end of the rector William Wood's account, he described how a man took hold of each of the maid's arms, who was 'prevailed with' to put out her foot and ask the spirit for a sign. The effect of this was then visible to the male observers since the maid's foot swelled 'exceedingly'. This test is particularly important for the dynamics of the narrative. It serves as a reminder of the reason for the transformation of this ghost story from a speech community to a manuscript, for Wood's account was a perfect example of the sort of richly detailed, circumstantiated report that the authors of printed supernatural collections sought as proof of the supernatural. It combined autobiographical exactitude with methodological probity, and used an experiment to affirm the testimony of the key witness. The experiment's success made the maid's evidence creditable, and allowed the testimony to be incorporated into the written narrative. Thus, although female witnesses were doubted, male scepticism could be overcome with a demonstration of acceptable proof. Ultimately, it was the maid's evidence that sustained the ghost story, prolonging the social pressure on both Fawcet and Johnson in the matter of the orphans' inheritance.

The gendered dynamics of the narrative do not end there. Intriguingly, Fawcet suggested that his wife might have played a key part in prompting him to take action in 1707 , some years after Madam Savage's death. Fawcet's narrative reported that he travelled to Leeds because of a particular concern that his wife might 'receive no damage by the fright' of the haunting, since she was at that time 'great with child'. Perhaps Mrs Fawcet had therefore been the key

23 Anon., Strange and true news from Long Alley, p. 7; Anon., The rest-less ghost: or, wonderful news from Northamptonshire, and Southwark (London, 1675), p. 6; Anon., The wonder of this age, p. 3; Anon., A most strange and dreadful apparition or several spirits and visions (London, 1680), pp. 3-4; Anon., A narrative of the demon of Spraiton... with a relation of an apparition or spectrum of an ancient gentleman of Devon (London, 1683), p. 4; Anon., A true relation of the dreadful ghost, pp. 2-3; Anon., The wonderful, strange, apparition and ghost, p. 6; Joseph Glanvill, A blow at modern Sadducism (London, 1681), quote p. $5^{6}$, other cases involving property pp. $235^{-6}, 23^{8 .}$ 
catalyst in the case, since her pregnancy equipped her with the emotional leverage she needed to convince her husband of the need to act. There are parallels here with the Bridget Pointon case, another of Thoresby's accounts where women played a key role in the dissemination of a story, which was passed on to Lady Dorothy Wentworth by way of her sister. In the account, Wentworth stated that she had heard the story of Pointon's experience from Mrs Jones, who was Bridget's sister and midwife to one of Wentworth's late children. Bernard Capp has demonstrated that the gathering of neighbours around the bedside of a woman in childbirth was one of the most important manifestations of female social interaction, and it seems plausible that the story was being discussed amongst the group of 'gossips' that attended to Lady Wentworth during her labour. ${ }^{24}$ Jones could also represent a more creditworthy female witness, since midwives were often witnesses in the law courts and may therefore have been seen as more credible relators of stories, information, and evidence. Though the evidence in both these cases is merely suggestive, it is reasonable to assume that female gossip played a key part in ghost stories, especially since this follows the arguments of Laura Gowing and Sasha Handley that women could draw on the authority of supernatural forces when formulating narrative strategies to expose domestic misdeeds. ${ }^{25}$ This appears to be the dynamic at work in the disturbance in the Easington household, which had its origins in a maid of the family whose master forbade her from marrying the man she was 'deeply in love with'. The maid pined away and died as a result, and ever since the house had been haunted by a spirit in her likeness. This explanation was reported by servants in the house, and it was a means for them both to condemn implicitly the master's actions, and to broadcast this moral censure beyond the household. Gender therefore seems to have been central to the Fawcet case. Whilst there were many male witnesses to the ghostly knocking, the sole purpose of the ghost was to carry out the wishes of a woman, and various other women appear to have played a key part in proliferating this ghost story. This strategy enabled these women to intervene indirectly in a property dispute in a manner that did not disturb contemporary expectations, since they co-opted the authority of supernatural forces in order to expose misdeeds and seek restitution from men.

One final aspect of the Savage case deserves attention, and that is its conclusion. When Johnson refused to return any property to the Thoresby orphans, Fawcet, 'in a discontented humour', saw fit to make use of the services of a reputed conjuror or wise man, William Bowes. Bowes told Fawcet that the ghost was a good spirit, and therefore that it should not be exorcised. Instead, Bowes gave Fawcet 'a form of speech' designed merely to get the ghost out of the house. As you would expect of a late seventeenth-century

${ }^{24}$ Bernard Capp, When gossips meet: women, family, and neighbourhood in early modern England (Oxford, 2003), pp. $5^{\mathrm{O}-1 \text {. }}$

${ }^{25}$ Handley, Visions of an unseen world, pp. 88-91; Gowing, 'The haunting of Susan Lay'. 
clergyman, the rector William Wood strongly disapproved of Fawcet's use of a conjuror. When he heard of it later, he rebuked Fawcet for following such a sinful course. Yet the words given by the conjuror were not only successful, they were also not particularly unorthodox, merely ordering the spirit to leave with the phrase: 'I charge thee by the holy and blessed Trinity to depart this house.' In printed pamphlets, there are similar cases of consultation with cunning folk, strongly suggesting that seeking out the services of a cunning person was a common response to hauntings. ${ }^{26}$ The incident is a reminder of the variety of attitudes that existed in relation to the meanings of and appropriate responses to apparitions when they appeared.

The Madam Savage account reinforces what printed ghost stories have demonstrated about the key functions and characteristics of ghost stories. The one noticeable difference is that Thoresby's apparitions are rather less theatrical than their printed equivalents. Thoresby's ghosts do not return to denounce murderers or to reveal the location of long buried bones. They do not appear still swaddled in their winding sheets, nor do they bring a 'brimstone stink' along with them. Candles do not burn blue, and spirits appear at all times of the day and night, not just at the witching hour. ${ }^{27}$ Unlike their pamphlet counterparts, Thoresby's ghosts deal in more quotidian wrong doing. A degree of exaggeration or embellishment in the commercial products is not surprising since these titillating details undoubtedly helped the printed material to sell. Yet whilst the Thoresby accounts suggest that the everyday interventions of ghosts were just as important as their more dramatic appearances in print, when it comes to the social dynamics of ghost stories it is evident that manuscript and printed narratives functioned in comparable ways. The manuscripts indicate the typical response to apparitions, they reveal common expectations about why spirits appeared, and they sanction our understanding of the intellectual underpinnings and gendered dimensions of these accounts. Indeed, Madam Savage's ghost has many features in common with the apparition of Mary Veal who appeared to her friend Margaret Bargrave in 1705 . Sasha Handley has demonstrated how this ghost narrative also had a particular meaning in its domestic setting, unveiling men's misdeeds, lending authority to female voices, and articulating worldly concerns about mortuary practice and inheritance. ${ }^{28}$ These ghost narratives therefore bear comparison with more notorious cases of supernaturally disturbed households where it has been possible to reconstruct the particular social and cultural meanings of printed cases. There are strong similarities with the infamous 'Drummer of Tedworth', a noisy poltergeist that haunted the house of John Mompesson in the 166os, and with the

${ }^{26}$ Cunning folk or conjurors are mentioned in Anon., Strange and true news from Long Alley, pp. 7-8; Anon., Strange and wonderful news from Lincolnshire (London, 1679), p. 4; Anon., A full and true account of a strange apparition... in Cherrey-Tree-Alley (London, 1685), p. 3 .

${ }^{27}$ All the behaviour described here is taken from the pamphlets previously mentioned in this article.

${ }^{28}$ Handley, Visions of an unseen world, ch. 3 . 
apparition that caused a sensation in a lodging in London's Cock Lane in the ${ }_{1760 s .}{ }^{29}$ Both of these cases involved interrogatory knocking, the crude form of communication used by the ghost of Madam Savage. Historians have demonstrated that these domestic disturbances also had their roots in the politics of the household, local conflicts, and personal relationships, and women and servants played prominent roles as the narratives progressed. Thoresby's private papers afford us with some additional context for the appearance of Madam Savage, but frustratingly, Thoresby does not explicitly discuss the ghost in his life-writing. We learn from his surviving correspondence that the story of the knocking ghost was circulating among Thoresby's social circle, suggesting a wider interest in the story at the time, but these letters merely mention the written account, rather than commenting on it directly. $3^{\circ}$ Yet the Thoresby manuscripts also suggest that translation into print potentially effaced some of the more personal resonances of ghost narratives. Printed ghost stories rarely offer an insight into individual responses to ghosts, nor do they usually allow for a reconstruction of the meaning and significance of these tales on the part of those who repeated, circulated, or recorded them. Whereas printed material is a guide to common expectations about spirits and their social significance, the Thoresby collection, in combination with his lifewriting, provides us with a rare subjective angle on apparition narratives. The next section therefore supplements the social resonances of the ghost stories with an examination of the peculiar interest that Thoresby had in these narratives, to demonstrate the emotional and religious sensibilities that such accounts were enmeshed in.

\section{I I}

Perhaps the most unique and striking feature of Thoresby's narratives is the strong similarity in the types of supernatural activity that they record. Apart from Fawcet's knocking ghost and the spirit that appeared to Bridget Pointon as a speaking pigeon, all the other instances relate either to likenesses that appeared to relatives and friends at the precise moment of a person's demise, or to 'living ghosts' that were actually seen before the death of the people they resembled. This preoccupation with ghosts that appeared at the time of, or shortly before, a person's death strongly suggests a particular interest in

${ }^{29}$ Hunter, 'New light on the "drummer of Tedworth"; Paul Chambers, The Cock Lane ghost: murder, sex and haunting in Dr Johnson's London (Stroud, 20o6); Handley, Visions of an unseen world, ch. 5 .

$3^{\circ}$ For instance, William Nicholson the bishop of Derry and Carlisle, a bishop of the nonjuring Church of England, and the vicar of Sheffield all wrote to Ralph Thoresby in 1707 asking for more details about the 'knocking ghost', suggesting that the manuscript account was circulating and being discussed by a group of correspondents: University of Leeds Brotherton Library Special Collections, YAS MS1 2, letter from George Hickes to Thoresby dated 5 July 1707; YAS MS8, letter from Nicholson to Thoresby dated 4 Sept. 4 1707; YAS MS12, letter from Nathan Drake to Thoresby dated 27 Nov. 1707. 
this specific phenomena, and as I will show it was closely connected to Thoresby's own personal lived experience, his religious beliefs, and his understanding of soteriology.

Thoresby's papers include a variety of 'living ghosts' that were seen shortly before, or at the moment of, a person's decease. In her narrative recording events in Ireland in 1711, Lady Piers, wife of Sir Henry Piers of Tristernagh, Westmeath, related that the 'appearance' of her coachman, Edward Fielding, passed by her when she was in her chamber. Perceiving that Fielding seemed to be 'confused' and 'in some disorder', Piers called out 'Ned, how dos $\mathrm{Sr}$ Henry', but Fielding did not reply, and when she looked into the part of the chamber that Fielding seemed to have gone into, she could apprehend nothing there. Piers was initially just annoyed by Fielding's heedlessness, since it was only some time later that she heard Fielding had died in Dublin at eight o'clock that day-precisely the moment that she had, impossibly, seen the coachman walking in her chamber more than ninety miles away. The house in Easington that Edmund Spencer wrote to Richard Baxter about was similarly said to be 'haunted against the death of any of the family'. Spencer had been chaplain to the Overton family, and he noted that eight years before he arrived, a vicious man of the town had died, and at 'the instant of his expiring' a spirit 'set up a bellowing under the window and ran up the street into the churchyard at the end of it, continuing his noise all along'. Ever since, if anyone died in the street in question, the spirit would make a noise under their window. Spencer was initially sceptical about the story, until one night the spirit came under his own study window and 'fetched such a groan as no creature ever I saw cold make', waking up the maids sleeping by the kitchen fire, scaring the family, and setting the dogs howling and trembling. Later, they discovered that a poor blind fellow of the town had died that very night.

As well as spirits that manifested at the moment of a person's death, Spencer also wrote of three instances of 'watching' the churchyard on St Mark's Eve. This was a practice that Richard Bovet mentioned in his printed collection, although he thought that it was associated with Midsummer Eve rather than St Mark's. ${ }^{31}$ Spencer and Bovet reported that two watchers would go to the churchyard at night, and stand within sight of the porch. At a certain time, the likeness of all those in the parish that would die that year would pass by the watchers and enter the church, appearing in the order that they would expire. Both authors then went on to give specific instances of watching. Spencer had been told that the church at Patterington had been watched and 140 people were seen to pass into the church. That year, plague visited the town and many inhabitants subsequently became victims of the epidemic, including the watchers themselves. In another instance, a farm labourer who

$3^{1}$ Bovet, Pandaemonium, pp. 216-18. Keith Thomas discusses this practice in Religion and the decline, p. 286. 
heard the church bell tolling was able to predict for whom it rang, since coming 'over the church garth late one night' the likenesses of twelve people of the parish passed him by whilst he had no power to stir.

Spencer and Bovet were somewhat doubtful about the practice of watching the churchyard on certain evenings of the year, though their concerns were not dismissive. Rather, they were anxious that this practice might gain its potency from the intervention of the devil. Spencer heard that Easington churchyard itself had been watched, resulting in the confident prediction that an old woman, one of Spencer's occasional hearers, would die the same year. Yet Spencer noted that his informers 'or the devil' were mistaken, since the woman lived on. Similarly, Bovet thought that though there might be 'magical days and seasons', it was 'probable' that the appointing of times and hours was 'of the Devils own Institution...that having once ensnared people to an Obedience to his Rules, he may with more facility oblige them to a stricter Vassallage'. ${ }^{2}$ This speculation about diabolic involvement indicates that watching the churchyard aroused more doubts in Spencer's mind than the other supernatural phenomena that he mentioned in his letter. Perhaps the practice of attempting to solicit sightings of apparitions in churchyards bore too much resemblance to sorcery, whereas the spontaneous disturbances in the Easington haunted house were less open to manipulation by evil spirits. In combination with a rather 'popish' reliance on the particular significance of a specific day, and the common practice of fasting in preparation for a watching, the practice also had other uncomfortable associations that the other apparitions narratives did not.

By contrast, other individuals in the Thoresby papers were less circumspect about instances of 'watching'. In a letter dated 26 November 1706 from William Edmundson to Reverend Benson, the lecturer of the 'Old Church' (St Peter's) in Leeds, Edmundson delivered news 'from unquestionable hands' that on the previous Midsummer's Eve, two boys from Winchester school had watched in the chapel. One boy fell asleep, whilst the other saw the likeness of the chaplain of the College (Mr Carman), the bishop of Winchester, and the other sleeping boy go up to the altar and then disappear. When the other boy awoke, he said that he had dreamt the same thing, and he predicted that he would die on 12 September. Edmundson, a resident of Winchester, added that Carman had died soon after, the boy on the day he predicted, and the bishop before Christmas, just as had been foretold. Together, these narratives reinforce the sense of ambiguity attached to the nature and meaning of ghostly manifestations - here there is no trace of the sense of scepticism and disapproval found in the other examples. They also raise the possibility that Thoresby was either gathering a particular type of narrative (those associated with the moment of death and living ghosts), or that as he assembled

$3^{2}$ Bovet, Pandemonium, p. 218. 
his narratives he was sorting them into categories as part of his preparation for publication.

Contextual evidence from Thoresby's life-writing suggests that he did have a particular interest in prognostications, especially those relating to death or those delivered in dreams. Early modern dream theory distinguished between vain and true dreams, with the latter being inspired by a demonic or divine external supernatural agent, and this supernatural quality meant that true dreams were usually prophetic, as was the case with the Winchester schoolboy. 33 The Thoresby papers include another example of a prophetic dream of death, copied out of the pocket book of John Mauleverer by his brother, and then passed on to Thoresby. 34 Not only that, but Thoresby also mentioned the instances of 'such as have had signal Warnings of their Deaths, by remarkable Dreams, Apparitions \&c.' in the appendix of 'unusuall accidents' that was published at the end of his Ducatus Leodiensis in $1715 .{ }^{35}$ In the appendix, Thoresby included two cases where people seemed to gain prophetic knowledge of a friend's demise at the moment of their death. ${ }^{36}$ Thoresby's life-writing further confirms his interest since he mentioned his own dreams on several occasions, one of which was prophetic, if rather mundane. Around May 1702, Thoresby dreamt that his friend William Nicholson had been advanced to the bishopric of Carlisle and on the strength of this wrote him a letter of congratulation though he did express concern lest it should in the end prove only 'a common dream'. 37

The origins of Thoresby's preoccupation with prognostication are probably to be found in his father's death in 1679 , when Thoresby was twenty-one. John Thoresby died very suddenly during the night of 30 October, being found dead on his bed 'upon his knees and face' the next morning, which was All Hallow's Eve. Thoresby's life-writing reveals that this was a great shock to him, and it began a long period of mourning for the 'inestimable loss of the best of fathers'. Indeed, throughout the rest of his life, Thoresby continued to remember his father in his diary, memorializing him as a role model and particularly as an archetype of the unwavering devotional regimen that Thoresby aspired to. Initially, Thoresby was especially disturbed by the abruptness of his father's demise, and he was deeply affected by it, unable even to perform his usually religious devotions. But it appears that Thoresby's interest in

33 For early modern dream theory, see Katharine Hodgkin, Michelle O'Callaghan, and S. J. Wiseman, eds., Reading the early modern dream: the terrors of the night (London, 2008), esp. Erica Fudge, “'Onely proper unto man”: dreaming and being human', pp. 37-9.

34 Thoresby was an acquaintance of John Mauleverer's brother Nicholas, a scholar and author who lived in the area - Thoresby mentioned visiting him several times in his diary.

35 Ralph Thoresby, Ducatus Leodiensis, or, The topography of the ancient and populous town and parish of Leedes (London, 1715 ), p. 626.

$3^{6}$ Ibid., p. 614 .

37 University of Leeds, Brotherton Library Special Collections, YAS MS26, p. 188 . Thoresby also refers to his dreams at pp. 43, 44, 47, 65, 252. Thoresby mentioned the Nicholson dream in his 'memoir' - a retrospective summary of his life that he began writing in 1710 . 
prognostication may have provided emotional solace for him, for it allowed him to construct a new story about his father's death that fitted more closely to his expectations about dying and the afterlife.

Reflecting on the fateful evening in his memoir, Thoresby recalled his father's final actions, when he read and explained the last book of Lamentations in family prayer. He became convinced that his father had insisted 'longer than was his ordinary custome' upon the applications of the chapter, expressing the 'greatest fervency' and 'remarkable ardor' in prayer afterwards. Thoresby speculated that his father's exceptional diligence and emotion in family prayer that night was due to his soul becoming 'receptive of a kind of prognostick or prophetick influence' that allowed it to presage its departure, and he concluded that 'truly I think that he enjoyed this blessing from God as a forewarning'. ${ }^{8}$ This theory was no doubt comforting to Thoresby as he came to terms with the very sudden, unexpected death of his father. Though the Protestant deathbed was no longer the site for a supreme test of faith as it had been in the pre-Reformation era, the behaviour of a dying person was still imbued with cultural significance, and notions of good and bad deaths were widely accepted and acted upon. Sudden death was a crucial example of the latter, and it was included in the list of evils in the Litany from which parishioners prayed for deliverance. Ostensibly, John Thoresby's was a bad death: the nature of his final illness had allowed no time for the orderly settlement of his worldly affairs, or for critical spiritual preparations and the full acceptance of God's will - all key ingredients of a 'good death' in early modern England. 39 Indeed, John Thoresby's passing contrasted powerfully with the 'good death' of an uncle on Thoresby's mother's side, who died four months after John Thoresby in February 1680. Thoresby was present at Thomas Idle's deathbed, and the narrative of his final days in Thoresby's diary epitomizes how to die well. As Idle's 'bodily strength decayed, so his faith increased'. He carried himself with patience, called his nearest relations to him to offer consoling advice, and with his final words blessed God and expressed his willingness to leave a world 'so full of trouble and sorrow'. $4^{\circ}$ John Thoresby's death, alone, unanticipated, with no final exhortations or prayers, must have been a painful contrast to Thomas Idle's peaceful passing in Thoresby's early, raw months of grief.

Yet if Thoresby was right, and God sometimes granted people supernatural forewarning of impending deaths, then this was a notion that he could draw comfort from. It was also a possibility that Thoresby would have encountered in the printed collections that he was familiar with. Though examples are

$3^{8}$ University of Leeds, Brotherton Library Special Collections, YAS MS26, p. 24.

39 See Ralph Houlbrooke, Death, religion and the family in England, I480-I750 (Oxford, 1998), ch. 7; L. M. Beier, 'The good death in seventeenth-century England', in Ralph Houlbrooke, ed., Death, ritual and bereavement (London, 1989).

$4^{\circ}$ University of Leeds, Brotherton Library Special Collections, YAS MS2 1, pp. 110-11. 
relatively rare in most of the collections, the exception is William Turner's exhaustive catalogue of providences, where the sections on the appearance of separate souls and the discovery of future things by signs and voices furnish numerous examples of living ghosts and apparitions that appeared at the moment of death..$^{1}$ The possibility of a foreshadowing certainly influenced the way that Thoresby remembered his father, allowing him to remodel John's deathbed experience into one that more closely resembled the ideal. The prophetic influence perceived by Ralph meant that John Thoresby was given the chance to offer edifying expressions of faith and hope to his family during evening prayer, just hours before his death. In fact, Thoresby went so far as to suggest that his father's sudden death could be interpreted as a blessing since it spared John the miseries of lingering sickness and the temptations of the deathbed. $4^{2}$ In combination with an assumption that his father's death was an expression of divine displeasure at his own, rather than his father's sins, Ralph was able to reject the impulse to interpret his father's sudden passing as a temporal judgement, or a sign of God's anger, and instead he found a way to make it conform to the perception of a good death.

Thoresby therefore had a very personal interest in uncovering and assembling other examples of prophecies relating to death, which could explain why so many of the apparition narratives in his papers relate to the theme. As a group, and viewed in the light of his life-writing, these narratives indicate the way that Protestant soteriology placed particular strain on individuals at the time of dying. Whilst Thoresby and many of his fellow parishioners accepted predestination, this sat awkwardly alongside a continued belief that the last acts of a person's life had some bearing on or gave a clue to the fate of their soul. In combination with a puritanical search for a feeling of assurance and grace and a heightened sensitivity to providential signs, these narratives may represent the urge to find ways to anticipate when those final acts might take place and to soften the harsh Calvinist doctrine of salvation. The Thoresby narratives can be contrasted with the many printed ghost stories that have a strong secular flavour, where ghosts returned to seek revenge, to detect murderers, or to enforce the terms of a will. As a result, these pamphlet ghosts can seem somewhat detached from religious cultures, their purpose to alter relations between the living rather than intervene in the relationship between the living and the dead. But narratives about the moment of death and the attempts by individuals to predict who might be the next in the community to die add a new dimension to the meanings of early modern ghosts. Reinstating the cultures of belief surrounding the Thoresby narratives restores this religious

$4^{1}$ Turner, A compleat history, Part I, esp. pp. $34^{-4} 4$ and $47^{-} 54$.

$4^{2}$ For these temptations, see Peter Marshall, 'Angels around the deathbed', in Peter Marshall and Alexandra Walsham, eds., Angels in the early modern world (Cambridge, 2006); Alec Ryrie, Being Protestant in Reformation Britain (Oxford, 2013), pp. 464-8. 
dimension and indicates a preoccupation that is missing in the apologetic collections of clergymen and the entertaining ghost stories of cheap print.

\section{V}

The collection of apparition accounts in Thoresby's archive have demonstrated the social relevance that ghost stories retained in local contexts. They exhibit undercurrents of traditional, shared understandings about what ghosts were like and what they did, and why the dead might return to the land of the living. They also verify the continuing legitimacy and authority of oral testimony, and demonstrate how empirical methods could lend authority to such evidence. Thoresby's papers therefore provide a rich example of these stories as effective narrative strategies that could be called upon and put to use in daily life. Beyond the pages of the narratives themselves, the curiosity that appearances of ghosts provoked is also apparent as Thoresby's correspondents wrote to him seeking further information or exchanged the narratives with other acquaintances. The accounts also display the range and variety of responses to ghosts among clergymen and layfolk alike, which ranged from scepticism, through concerns about diabolical activity, to seemingly unproblematic acceptance that ghosts could sometimes appear to the living.

Beyond these social and often secular dynamics, the Thoresby accounts have also revealed much more. For there is a different story to be told about the window that they provide on the spiritual imperatives that could sustain an interest in these accounts, and the religious sensibilities that ghost stories were intimately connected to. The collection can therefore provide a sense of the continuing importance of ghosts within religious cultures, particularly in relation to individual belief and the significance that these stories had for those who encountered them. If part of the reason for the layering of traditional and Protestant expectations about ghosts is to be found in a clerical response to pastoral realities, then the Thoresby narratives take us closer to that reality, suggesting the effects of that strategy amongst the laity. 43 For Thoresby's preoccupation with 'living ghosts' suggests that he associated these apparitions with questions of salvation, predestination and providence, central theological issues that are less evident in print-perhaps the entertaining and polemical purposes of cheap print and supernatural collections conceivably did not leave room for such dynamics.

The question remains: how representative is Thoresby of attitudes towards ghosts at the time? There is no doubt that the Yorkshireman was a hotter sort of Protestant, and that as a peculiarly devout individual, the depth of his spiritual commitment was not shared by the majority of his contemporaries. However, an interest in living ghosts was not restricted to Thoresby alone. Indeed, all of the accounts of living ghosts in the Thoresby archive were sent

43 Marshall, Beliefs and the dead, p. 249. 
to him, and the narratives featured individuals from across the social hierarchy. As already mentioned, examples of living ghosts can be found in many of the printed supernatural collections of the seventeenth century too. The examples in Turner's collection are in fact very similar to Thoresby's, though in many cases they are less detailed and the names of the individuals involved have been omitted. Moreover, although Thoresby was a fervent believer, a belief in predestination was not limited to others who shared his religious sentiments; rather, it was a central element of English Protestantism throughout the postReformation era.44 Though not everyone would have grasped the niceties of the doctrine of salvation, undoubtedly there were those that did, including many, like Turner, who were of a conformist inclination. Of course, although these other people showed an interest in living ghosts, it does not necessarily follow that they invested them with the same spiritual significance as Thoresby. Yet even if Thoresby's collection is considered as one unique snapshot, his manuscripts allow us to reconstruct the nature of his interest in apparitions, and to trace how an individual responded to ghostly narratives. His personal and emotional responses give us pause for thought about the religious contexts in which ghost stories were embedded, and demonstrates that the significance afforded to supernatural narratives could be strongly spiritual, long after apparitions had been 'reformed'.

44 The exact status of the doctrine of predestination in English religious cultures has been fiercely disputed: see Nicholas Tyacke, Anti-Calvinists: the rise of English Arminianism, c.1590I640 (Oxford, 1990); the debate between Tyacke and Peter White in Past and Present, 118 (1987), pp. 201-29; and Alexandra Walsham, 'The parochial roots of Laudianism revisited: Catholics, anti-Calvinists and "parish Anglicans" in early Stuart England', Journal of Ecclesiastical History, 49 (1998), pp. 620-51. 